\title{
Pisces, Gymnotiformes, Hypopomidae, Brachyhypopomus draco (Giora, Malabarba and Crampton, 2008): New species record at Lagoa do Peixe National Park, state of Rio Grande do Sul, Brazil
}

\author{
Marlucy Coelho Claudino*, Fabiano Corrêa, Rodrigo Ferreira Bastos and Alexandre Miranda Garcia \\ Universidade Federal de Rio Grande, Instituto de Oceanografia, Laboratório de Ictiologia, Campus Carreiros. Caixa Postal 474. Rio Grande, RS, \\ Brazil. \\ * Correponding author. E-mail: maluclaudino@hotmail.com
}

\begin{abstract}
The present paper describes a new occurrence of the species Brachyhypopomus draco in a wetland area of the Lagoa do Peixe National Park, state of Rio Grande do Sul, Brazil.
\end{abstract}

The Family Hypopomidae is one of five nominal families of the Order Gymnotiformes Reis et al. (2003), all of which produce weak electric impulses for the purposes of communication and electrolocation (Sullivan and Hopkins 2009). This family is comprised of approximately 19 species (Loureiro and Silva 2006; Sullivan and Hopkins 2009). As proposed by Albert and Crampton (2003), the species of Hypopomid family are identified by the following morphologic characters: teeth absent from both jaws, snout's length from moderate to short, small eyes, a nasal capsule near the eye, anterior nares located outside gape, infraorbital bones ossified as slender tubes, operculum trapezoidal, hyomandibula oriented oblique to long axis of head, anal-fin origin ventral or posterior to pectoral finbase and no caudal fin or dorsal organ. Brachyhypopomus draco Giora, Malabarba and Crampton, 2008, is a electric fish belonging to the Hypopomidae family that has been recently described by Giora et al. (2008) (Figure 1). These authors characterized the species by the presence of urogenital papilla in females and males, although less developed in juveniles; pectoral fins rounded with pigmented rays and perpendicular insertion; pectoralfin rays $\mathrm{i}-\mathrm{ii}+13-15$ (15-17 total pectoral-fin rays, $\mathrm{n}=47$, median = 16). Anal fin relatively long with vii-xii $+148-186$ rays (155-198 total anal-fin rays, $\mathrm{n}=41$, mean $=181.3$ ) which are pigmented. Anal-fin origin located posterior to posterior edge of pectoral fin. Precaudal vertebrae 2123 (20-22 anterior, 1-2 transitional; $n=6)$. This species is widely distributed in the Rio Grande do Sul (RS) state, occurring in its central, southern and coastal regions and it is also found in Uruguay, Argentina and Paraguay (Giora et al. 2008). Brachyhypopomus draco inhabits lagoons, rives edges, slow moving creeks and flood areas with abundant floating vegetation.

On February $20^{\text {th }}, 2009$, we collected three female specimens of $B$. draco (average total length, TL, of $61 \pm$ $19 \mathrm{~mm}$ and average weight of $0.68 \pm 0.38 \mathrm{~g}$ ) in a wetland $\left(31^{\circ} 6^{\prime} 5.10^{\prime \prime}\right.$ S, $\left.50^{\circ} 51^{\prime} 16.71^{\prime \prime} \mathrm{W}\right)$ located approximately
$6 \mathrm{~km}$ east from the city of Mostardas in the Lagoa do Peixe National Park (LPNP) (Figure 2). Our current records extend $81 \mathrm{Km}$ southeastern the previous known distribution of the species and also represent its first record in a national park located along the RS coastline (Figure 2). Individuals of $B$. draco were collected with a small seine net $(1 \times 1 \mathrm{~m}$ of opening and with size mesh of $5 \mathrm{~mm}$ ) altogether with several other species during a research field trip conducted by the Ichthyology Laboratory of the Rio Grande Federal University, FURG (SISBIO's license for field collection number 14443-1). Specimens were preserved in $10 \%$ formalin and later identified at the Ichthyology Laboratory based primarily on Giora et al. (2008). Specimens examined were deposited at the Ichthyology Laboratory in the same university (catalogue number FURG2186).

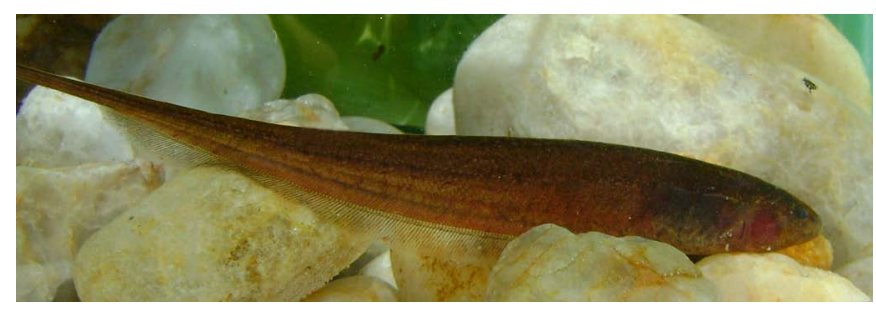

FigurE 1. Picture of female Brachyhypopomus draco collected in a wetland area of the Lagoa do Peixe National Park, Rio Grande do Sul state, Brazil (Picture by Fabiano Corrêa).

Recently, an extensive fish inventory conducted by Loebmann and Vieira (2005) did not found this specie of electric fish among the 73 fish species they reported to occur in several freshwater and estuarine sites of the LPNP. The present work reports for the first time the occurrence of $B$. draco in the LPNP, which is considered as a "Biosphere Reserve" by UNESCO and was declared a national park by Brazilian authorities in 1986. The occurrence of this recently discovered electric fish species inside the LPNP highlights the urgent need to reinforce conservation actions aiming to protect its aquatic habitats, 

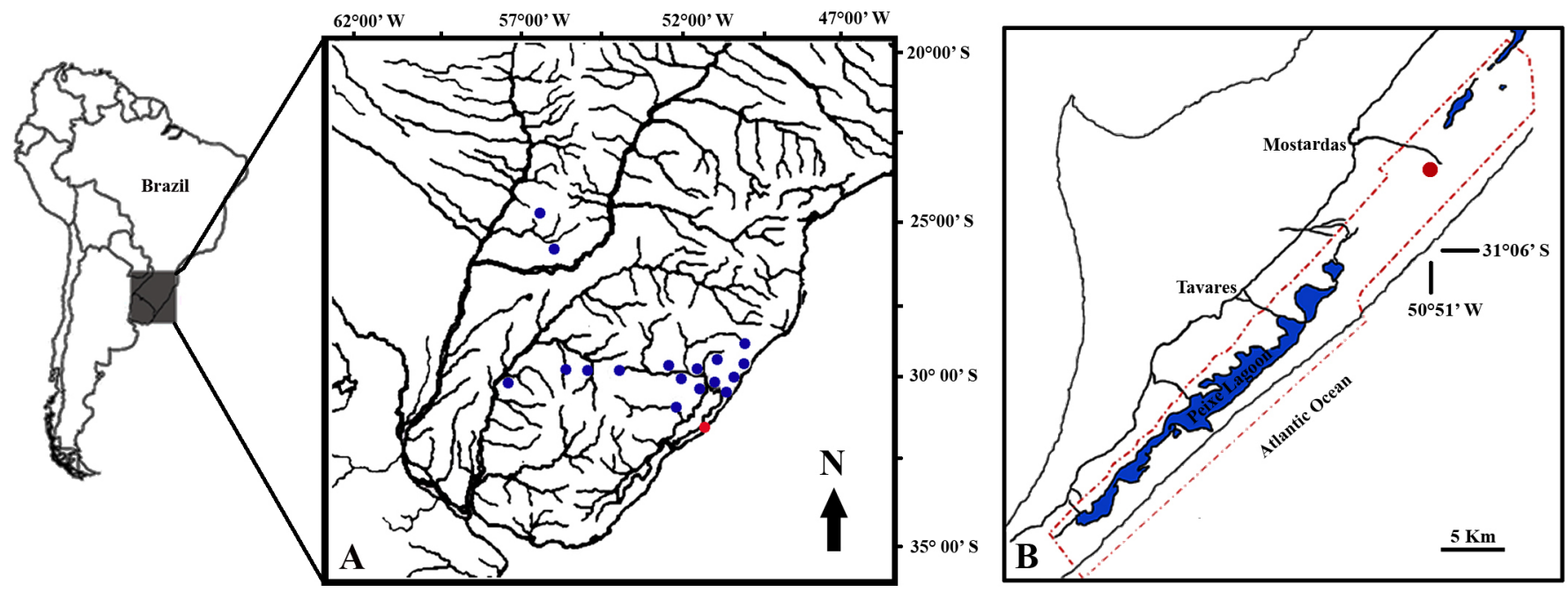

FIGURE 2. Southern Brazil (A) and the Lagoa do Peixe National Park (B) showing the location of wetland area where the specimens of Brachyhypopomus draco were captured. Blue dots denote the previous known geographic distribution of B. draco. The red dot denotes the current record of $B$. draco inside the borders of the Lagoa do Peixe National Park.

including marginal areas that are seasonal flooded. Ongoing anthropogenic impacts related to private land use within the park, such as cattle grazing and farming, could pose serious threats to his habitats and, consequently, to the future maintenance of this new fish species in the LPNP.

\section{Literature Cited}

Albert, J.S. and W. Crampton. 2003. Family Hypopomidae (Bluntnose Knifefishes) In: Reis, R. E., S.O. Kullander and C.J. Ferraris Jr. (Eds.). 2003. Check List of Freshwater Fishes of the South and Central America. Porto Alegre: Edipucrs. 729 p.

Giora, J., L.R. Malabarba and W.G.R. Crampton. 2008. Brachyhypopomus draco, a new sexually dimorphic species of Neotropical electric fish from southern South America (Gymnotiformes: Hypopomidae). Neotropical Ichthyology 6: 159-168.

Loebmann, D. and J.P. Vieira. 2005. Composição e abundância dos peixes do Parque Nacional da Lagoa do Peixe, Rio Grande do Sul, Brasil e comentários sobre a fauna acompanhante de crustáceos decápodos. Atlântica 27(2): 131-137.
Loureiro M. and A. Silva. 2009. A New Species of Brachyhypopomus (Gymnotiformes, Hypopomidae) from Northeast Uruguay. Copeia 4: 665-673.

Reis, R.E., S.O. Kullander, and C.J. Ferraris, Jr. (Eds.). 2003. Checklist of the freshwater fishes of South and Central America. EDIPUCRS, Porto Alegre, Brasil. 729 p.

Sullivan, J.P. and C.D. Hopkins. 2009. Brachyhypopomus bullock, new species of electric kinfefish (Gymnotiformes: Hypopomidae), from northern South America. Proceedings of the Academy of Natural Sciences of Philadelphia, 158: 183-192.

RECEIVED: April 2010

REVISED: April 2010

ACCEPTED: May 2010

PUBLISHED ONLINE: August 2010

EDITORIAL RESPONSIBILITY: Javier A. Maldonado 0. 